This item was submitted to Loughborough's Research Repository by the author.

Items in Figshare are protected by copyright, with all rights reserved, unless otherwise indicated.

\title{
Kindred spirits: Doing family through craft entrepreneurship
}

\author{
PLEASE CITE THE PUBLISHED VERSION
}

https://doi.org/10.1177/0038026120916131

PUBLISHER

SAGE Publications

\section{VERSION}

AM (Accepted Manuscript)

\section{PUBLISHER STATEMENT}

This paper was accepted for publication in the journal The Sociological Review and the definitive published version is available at https://doi.org/10.1177/0038026120916131 Users who receive access to an article through a repository are reminded that the article is protected by copyright and reuse is restricted to noncommercial and no derivative uses. Users may also download and save a local copy of an article accessed in an institutional repository for the user's personal reference. For permission to reuse an article, please follow our Process for Requesting Permission.

\section{LICENCE}

In Copyright

\section{REPOSITORY RECORD}

Thurnell-Read, Thomas. 2020. "Kindred Spirits: Doing Family Through Craft Entrepreneurship". Loughborough University. https://hdl.handle.net/2134/12212543.v1. 
Kindred Spirits: Doing Family through Craft Entrepreneurship

Thurnell-Read, T. (2020). 'Kindred Spirits: Doing Family through Craft Entrepreneurship', Sociological Review

https://doi.org/10.1177/0038026120916131

\section{Dr Thomas Thurnell-Read}

School of Social Sciences and Humanities

Loughborough University

Loughborough

LE11 3TU, UK

Email: t.thurnell-read@lboro.ac.uk 


\section{Kindred Spirits: Doing Family through Craft Entrepreneurship}

Dr Thomas Thurnell-Read

Loughborough University

\section{Introduction}

Entrepreneurial labour has been described as an expression of selfhood and individual identity (Bröckling, 2015) which is supported by a widely accepted 'cultural myth' that the domains of work and family are distinct and separate (Fitzgerald and Muske, 2002). However, as part of debates which have sought to challenge this dichotomous separation of work and non-work spheres (Land and Taylor, 2010; Smith Maguire, 2017), there has been a move to explore the 'increasingly porous' boundaries between the personal and professional lives of entrepreneurs (Wee and Brooks, 2012, p. 574) and to better understand the ways in which some occupational cultures 'strongly value the blurring of boundaries between work and leisure, and between friends and formal work relations' (Cederholm \& Åkerström, 2016, p. 751). Additionally, the resurgence of academic interest in the concept and practice of craftwork (e.g. Sennett, 2008; Atkinson, 2013a; Luckman, 2015) means that the now numerous examples of craft enterprises, which see an individual or small group of skilled workers involved in creating and selling handmade or small-batch product directly to consumers, represent a valuable opportunity to explore the changing meanings of work and workplace relationships. Because craftwork is by its nature an expressive and immersive activity ( $O^{\prime}$ Connor, 2010), studies of craft enterprises are well placed to examine the ways in which craft entrepreneurs understand their own investment in their work and how such involves an intermingling of professional and personal identity.

This article adds to this recent drive to understand work and workplace relationships as important loci for the interconnection of work and non-work identities by drawing on qualitative interviews conducted with twenty craft drinks entrepreneurs in the UK. As many of these businesses are established and run in partnership between spouses, siblings or close friends, the article analyses craft enterprise not as a highly individualistic undertaking, but as a site in which occupational values, personal identity and interpersonal intimacies or, following Mason (2018), 'affinities' become animated. Thus, the article explores the performance of 'familiness' in such entrepreneurial contexts (Smith Maguire, Strickland, \& Frost, 2013; Barros et al., 2017). This article therefore contributes to recent work which has foregrounded the negotiation of at times problematic interpersonal relationships both within the burgeoning craft drinks sector (Kuehn \& Parker, 2018; Land, Sutherland 
\& Taylor, 2018) and in work more generally (Ekman, 2013; Greggs, 2013; Weeks, 2011). In doing so, it adds to the increasing body of literature that explores craft labour and creative economies (Atkinson, 2013a; Luckman, 2015), whilst also adding to debates about the nature of contemporary family and kinship (Finch, 2007; Smart, 2007).

The article is organised as follows. The next section highlights, first, a long running tendency noted above for work and private life to be treated as 'separate spheres' and, second, a more recent willingness to examine the multiple ways in which the personal and the occupational transect and overlap. The concept of craftwork is further examined in order to demonstrate why the recent emergence of craft enterprises, such as the gin distilleries which are the subject of this research, affords useful insights into the nature of workplace relationships and affinities. Next, a methodological section outlines the use of qualitative interviews and gives further contextual detail relating to the recent emergence of craft enterprises such as artisan gin distilleries. This is followed by a findings section which includes subsections which first outline the variety of ways in which friends and family are involved in the craft distillery enterprises and then the ways in which the intersection of entrepreneurial and familial features of the craft businesses are experienced and negotiated. Final, a concluding discussion will explore how, for these craft entrepreneurs, family and kinship are experienced as part of their work and not separate to it, and how working together provides situations and experiences through which personal relationships with spouses and siblings become experienced and enriched, but also commodified as a resource within the operations of the enterprise.

\section{Working lives and personal ties}

Previously, the intersections of family structures and entrepreneurship within family businesses had received limited academic attention (Randerson, Bettinelli, Fayolle \& Anderson, 2015), meaning that studies such as Mulholland's $(1997 ; 2003)$, which use family run businesses to examine a range of issues relating to work and kinship which are concerned the intersection of corporate and familial practices and identities, were notable for their scarcity. However, research on family business and entrepreneurship has expanded in recent years and there are now a number of academic journals dedicated to the subject including Family Business Review, Journal of Family Business Management and European Journal of Family Business. Within this subfield of business studies, there has been an expansion of the conceptual apparatus to illuminate and scrutinise the ways in which family and work are often 'inextricably intertwined' (Fitzgerald \& Muske, 2002; Aldrich and Cliff, 2003; Welsh et al. 2013) which has enabled scholars to address the previously limited understanding of how 
entrepreneurial cultures are transmitted and sustained' within and between generations of family businesses (Cruz, Hamilton \& Jack, 2012, p. 147).

Within sociology, however, there has long been a division between public work and private life, characteristically 'public' and 'private' respectively (Allen, 1996), as being the empirical and theoretical remit of either the sociology of work (Weeks, 2011) or the sociology of the family (Morgan, 1996) respectively. Thus, the 'dominant assumption' that 'work' and 'life' are two discrete spheres' (Land \& Taylor, 2010, p. 396) has been challenged and criticised both in the past (Finch, 1983; Jarvis, 1999) and more recently by both theoretical and empirical examinations of the blurred but overlapping edges of occupational identities and private lives. Glucksmann (1995, p. 65), for instance, has long urged for a consideration of how 'work is embedded in, entangled with, conducted and expressed through other activities and relations which may be social, political, kinship, sexual or familial'. Building on this, more recent work has shown how many features of modern work conspire to make such blurring of boundaries a necessary or, at least, unavoidable reality especially for workers in knowledge based roles in the creative and cultural industries (Naudin and Patel, 2017). Gregg (2013: 15) describes how both the practicalities of contemporary working conditions and the wider ethos that encourages a form of 'presence bleed', whereby 'the location and time of work become secondary considerations faced with a "to do" list that seems forever out of control'. Meanwhile, Weeks (2011: 4) interrogates what she terms 'work's privatization' resulting in a 'tethering of work to the figure of the individual'. Rather than a separate sphere, work has become an arena to prove and fulfil oneself in. A common feature of much modern work, then, is the imperative to invest yourself, your personality and selfhood, into your work and thereby participate in a process by which 'personal fantasies about existential potential' are entangled with 'corporate fantasies about economic potential' (Ekman, 2013: 1161).

Meanwhile, other scholars have sought to illustrate how the blurring of workplace and nonworkplace subjectivities is, for many, desirable and sought after. For example, Fincham (2008) has shown how work, labour, freedom, style and community attachment are inseparably bound up in the working lives of bicycle messengers, while my own study of 'microbrewers' examines how a personal passion for good beer is developed from an amateurish leisure pursuit into a holistic craft brewer identity based on skill, passion and the investment of oneself into one's labour (ThurnellRead, 2014). Similarly, Cederholm and Åkerström's (2016, p 755) research with Swedish equestrian entrepreneurs shows that indistinct work-life boundaries are a defining, and often desired, quality of the working experience that 'both physically and symbolically blurs the boundaries between home and work, and between private and public, since the very foundation of the enterprise is the owners' personal interests, lifestyle and residence' (Cederholm \& Åkerström, 2016, p. 755). 
Importantly, such studies show that 'while often conceptualized as binary opposites, work and leisure are better understood as interrelated social phenomena' (Smith Maguire, 2017: 420). Thus, riding bikes, racing horses or brewing beer are all activities that allow participants of these studies to wilfully engage aspects of selfhood that straddle the supposed working life-private life division.

\section{Crafting the entrepreneurial self}

A well-established cultural stereotype depicting entrepreneurs as highly autonomous, risk-taking individuals is upheld by politicians (Crang and Martin, 1991), academics (Bröckling, 2015), the mainstream media (Boyle, 2008), educational discourse (Morrin, 2018) and, not least, entrepreneurs themselves (e.g. Branson, 2008). However, recent empirical and conceptual work reveals the reality of entrepreneurial activity to be far more heterogeneous. The term entrepreneur is used in widely varied ways and might just as readily be used to describe the 'disruption'-fixated tech 'geeks' of Silicon Valley (Hashemi, 2019), the committed individuals who build careers out of their immersion in highly specific subcultural scenes (Snyder, 2012) or the women who supplement or replace both paid and unpaid work with trading and reselling of hand-crafted or second-hand items through online platforms such as Etsy and eBay (Lukman, 2015; Waight, 2019). Most relevant to the present study, the craft drinks and artisanal food businesses which have proliferated in the UK, the US and beyond in recent years exhibit many quintessentially entrepreneurial qualities (Cope, 2014; Ocejo, 2017). Notably, such small-scale artisan production involves a close alignment of product and producer where success may depend on how clearly the identity of the maker can be performed and communicated to customers and, further, may deploy tropes of individualism, rebellion and authenticity at the heart of which is an invariably male heroic figure (Land, Sutherland and Taylor, 2018; Thurnell-Read, In Press).

As with entrepreneurship, craftwork has been commonly framed by discourses which emphasise independence and autonomy (Dormer, 1994), knowledge and skills (O'Connor, 2005; Atkinson, 2013a; Atkinson 2013b; Thurnell-Read, 2014) and a capacity for self-exploration and expression (Korn, 2013). However, few studies have examined the interpersonal relationships involved in craft entrepreneurship. This is of particular concern given that entrenched narratives of self-employment that valorise individualistic agency and personal autonomy (Warr \& Inceoglu, 2018) are underpinned by the 'everyday actions that symbolically and materially create situations as business and not business, family and not family, home and not home and work and not work' (Bourne \& Calás, 2013, p. 426). 
Because both craftwork (Sennett, 2008; Thurnell-Read, 2014) and entrepreneurship (Taylor, 2015; Morrin, 2018) are underpinned by discourses of individualism and autonomy which are at odds with any attempt to empirically examine the nuances of the overlaps between work and non-working experiences and subjectivities, some of the recent advanced in the sociology of families and personal life may be drawn on here. This shift, inspired by Morgan's (1996) influential conception of family practices as 'doing family', foregrounds everyday practices and activities rather than either atomised individuals or reified family structures. It means that there has been an increased acknowledgement of 'the notion that a specific and new form of intimacy is increasingly dominating personal and public life' (Jamieson, 1998, p.13) and involves far greater recognition of the ways in which 'personal life is never still or stationary in the way that the old idea of 'the family' appeared to be' (Smart, 2007 , p. 29). Because these developments reveal the meaningful ways in which personal identity and interpersonal relationships are animated in and through a variety of contexts, not limited to the discrete space of the family home, a more expansive understanding of the roles, practices and intimacies of family life (Jamieson, Morgan, Crow, \& Allan, 2006) can here prompt an examination of the varied roles of peers and kin in craft enterprises.

Carrying on these themes, the following analysis will explore craft distillers accounts of the centrality of kinship to their experience and, further, how working together with intimate others both informs business practice and, in turn, shapes understandings of those relationships with partners, parents, siblings and close friends. This analysis therefore envisages the craft distillery as a place in which 'doing family' can be witnessed and analysed. As the following empirical data illustrates, craft entrepreneurship involves a blurring of personal and workplace identities and activities. In contrast to past tendencies to bifurcate work from non-work, interviewees are shown to be highly reflexive of the ways in which the two intersect. Further, the article seeks to show how the entrepreneurial self we encounter at work in the craft distillery is not a solely individualistic or autonomous entity. Rather, we see how affective practices and affinities (Gabb, 2008: Mason, 2008, 2018; Smart, 2007) are central to both the promises and challenges of craft entrepreneurship.

\section{Methods and context}

In the past decade there has been a surge in consumer interest in small batch spirits produced by independent 'craft' distillers with gin, in particular, experiencing increased cultural visibility and an associated rapid increase in sales (Taylor, 2018). This sudden expansion was in large part made possible by legal changes in 2009 which, for the first time in several centuries, permitted distillation licences to be granted to operations with a production capacity smaller than 1800 litres. Since then, there has been a rapid growth in the number of small and independent distilleries operating in the 
UK (Marston, 2018). The number of distilleries has doubled in a five year period to 2018 , including 42 new gin distilleries opening in 2017 alone, and the value of gin sales reaching $f 1.5$ billion in the 12 months to March 2018 (Dodd, 2018). At the time of writing, the Gin Guild lists 184 separate distilleries involved in making gin in the UK. Bound up with this account of shifting market trends are the experiences of the numerous people who have become involved in making and selling gin, often as part of a craft entrepreneurship model involving, at first, amateur experimentation progressively leading to small-scale business start-ups followed by, for many but not for all, expansion and increasing formalisation.

The research on which this article is based consisted of 20 semi-structured qualitative interviews conducted with UK-based craft distillery workers conducted between July 2017 and February 2018. Social backgrounds were diverse with the majority of participants self-defining, when asked, as being working-class or lower-middle class and roughly equal numbers reporting having or not having university level education. Five interviewees were female and the rest were male, and this was felt to reflect the general gender balance within the UK craft spirits sector and might be contrasted with a UK brewery sector dominated far more by male workers and male customers (Thurnell-Read, In Press; Rydzik \& Ellis-Vowles, 2018). Interviews were conducted in urban, suburban and rural locations from the far Southwest of England, across the Midlands and in Northern English cities. Interviewees were selected following initial analysis of a range of websites, business listings and promotional activities, including social media, with inclusion criteria being that businesses were independent and actively engaged in the production of the gin as opposed to relying on 'contract distilling' by another business. The interviews lasted between 45 minutes and two hours and were recorded with the consent of participants and then transcribed verbatim before being thematically analysed. Pseudonyms have been used throughout and identifying characteristics of distilleries, such as product names and business locations, have been avoided where possible.

While the role of family, kinship and friendship was not an initial 'sensitizing concept' (Charmaz, 2006) at the outset of the research, it quickly became apparent that such personal relationships required further exploration and analysis. To this end, the flexibility afforded by semi-structured interviews (Brinkmann \& Kvale, 2018) allowed questions about working practices and work-life balance to readily flow into discussions of private lives and personal relationships and their role in the businesses formation and continued activity. Of the 20 interviewees, it was possible to establish that eleven involved direct kinship ties in their business organisation (seven as spouse or cohabiting partner, three with siblings and one with offspring) and that a further four involved some form of significant friendship that pre-existed the creation of the distillery. Amongst the remaining interviewees, of whom three ran their distilleries singlehandedly and two worked in salaried roles, 
all five spoke at length about the social nature of their work meaning that the social, relational and interpersonal elements of their work featured prominently in their narratives.

\section{'It was me, a few close friends and a table full of booze': Familiness at work in craft enterprise}

In contrast to the wider cultural stereotype of the entrepreneur as an autonomous individualist (Bröckling, 2015), the narratives offered during interviews involved rich accounts of the meaningful role of family and friends in the experiences of entrepreneurial labour. It became clear that, for many, this involvement of family members in varied tasks across the business meant an enactment of 'familiness' that proved to be a valuable resource used within a firm (Smith Maguire, Strickland, \& Frost, 2013; Barros et al., 2017). Thus, many craft distillers recalled how they drew on family and friends as a source of informal ad hoc labour where, as Austin explained, 'you find mum, dad, an uncle, or whoever really, are willing to lend a hand partly in the hope of getting some nice free gin to drink at the end of the day'. Such is akin to the 'helping hands' identified by Cederholm and Åkerström (2016), where the intersection of gift and market economies becomes visible through the assistance and mutual support offered by friends and family. A significant number of the distilleries studied developed in this way, with family and friends being the tasters whose positive response would then provide the confidence to take the first steps in commercial enterprise. For instance, Terry spoke of a 'sort of summit' he held over 'a gloriously fun and boozy weekend' where 'it was me, a few close friends and table full of booze'. By bringing together trusted friends, as well as his brother and his aunt, to taste variations of his own home-distilled gin, Terry was able to cultivate his motivation by 'feeding off the buzz' generated by his close friends and family to signal a transition from being an amateur home-distiller to a professional craft entrepreneur.

Notably, several businesses, such as Paul's, 'grew out of the home' and were winning awards and securing significant contracts well before they moved to business premises external to the family residence. Likewise, Felix, a former property development manager in his late 20 s who had set up a distillery with his fiancé, spoke of their humble beginnings where 'we set the business up, we bought a 60 litre still...and the only space in the only room we could afford was our dining room'. Tellingly, from their initial meeting, where he recalled that they 'fell in love [by] spending far too long drinking gin', through their first business successes whilst still operating within the domestic space of their shared rented apartment, to their current expansion and their planned wedding for which they would be distilling a limited edition run of 'wedding gin' to be served at the reception and gifted to guests Felix offered an extended account of how his relationship with his girlfriend had been interweaved with the development of their gin distillery business. Thus, the story of their business is also that of their relationship such that both were recounted during the interview as well as being 
told as part of the brand story on their website and again in local news coverage. Notably, such accounts that emphasise intimate personal ties serve to foreground many of the values of authenticity, creativity and passion which are widely valued by consumers of craft drinks and artisanal foods (Thurnell-Read, 2019; Cope, 2014) and may be used by producers to differentiate 'from the large-scale brands against which they compete, and may be more likely to yield resonant and lucrative - quality claims' (Smith Maguire, 2013). Further still, they clearly draw on discourses of appropriate and desirable coupledom and thereby imbue their brand with value underpinned by wider structures of heteronormativity.

Another areas where 'familiness' is drawn upon to explain and support the activities of the distillery is invocation of family legacies. Jaqueline, for example, said that hers was 'a family distillery, it was started by my parents' and explained that whilst 'both my brother and I went off and had completely independent careers, doing totally different things' they had taken on the business in 2006 when 'Mum and Dad realized they wanted to retire' and called 'a massive family conference' to discuss the future of the business. A number of others spoke of inheriting craft skills and entrepreneurial dispositions from their parents and other relatives or from the context of their upbringing. Hamish spoke of a long history of home brewing in his family and of learning to brew and distil whilst as still a teenager, while for Rowena, being raised by parents who ran a brewery meant that she and her siblings had acquired an 'entrepreneurial mentality' through helping out at the brewery on the weekend as teenagers. This upbringing, where she 'knew that it wasn't ok to be watching TV on a Saturday', was identified by Rowena as inspiring her own entrepreneurial work ethic and resonates with earlier accounts of how entrepreneurial dispositions may be transmitted from parents to their daughters and sons (Bennet \& Dunn, 2000).

For those distilleries with an intergenerational history, such as Jacqueline's, there was a sense of inherited reputation, where such connections have been forged over time between family identity, company identity and the reputation of the product (Mulholland, 1997, p. 698). She described her parents' decision to hand the business on to her and her brother as 'a remarkable act of trust on their part' and then emphasised that with the business came 'a reputation for making really good quality things to drink' that both her and her brother felt 'duty bound to uphold'. Jacqueline and Chris emphasised this sense of legacy and inheritance, or following Welsh et al. (20130 'stewardship', as follows:

'We $100 \%$ own it, and we're in a position where we inherited it from our parents. My kids are now older teenagers. I think, you know, I want them both to go off and have their own careers, but I also 
would like to be able to think that, if they wanted to, that the business would eventually be handed on to them'

'I got the family involved because the kids have all got their own businesses and it was quite nice to involve them. So my son does all the branding, that sort of thing. We've tried to keep it within the family environment, something I've actually grown up with [...] it's been nice to involve them because they are now at the right age to get involved'

Such comments clearly illustrate the ways in which thinking about the past, present and future of both work and family where, for many of these interviewees, intertwined in profound ways.

The above analysis demonstrates that personal relationships, frequently those that involve intimacy with kin and close friendship are a palpable aspect of the craft distiller working life. Importantly, these connections go beyond simple pragmatic arrangements used during the earlier stages of entrepreneurial activity. Rather, what this section has outlined is closer to a form of affective labour based on relations and interactions similar to the 'affinities' described by Mason (2018, p. 2) as being highly potent connections that are lived through multidimensional encounters and sensations in personal life'. We see how the support of family and friends charges some distillers with an emotive energy that appears used as a resource from which to draw confidence in their work and products or, as with Rowena and Danny, to locate their activity as resonant of qualities and aptitudes transmitted from parents and grandparents (Cruz et al., 2012). As the following section will explore, these familial relationships and associated affective connections require negotiation and narration but, in doing so, provide a mean by which craft work appears to illuminate the performance of partnership and kinship.

\section{'We're making a living together': Balancing kinship and enterprise}

For a number of participants the craft enterprise was noticeably part of attempting the difficult task of 'co-ordinating home, work and family life' (Jarvis, 1997, p. 232) meaning that craft enterprises where readily attached to a range of moral, cultural and social values relating to work-life balance, family practices and community embeddedness (also see Paxson, 2013). For example, both Eddie and Archie spoke of having children as prompting them to reconsider their work-life balance and saw their craft enterprises as a means to achieve greater flexibility in their lives. Another male interviewee, Paul, spoke of quitting 'a decent well paid job that was fine and steady and paid the bills' to start up a craft gin distillery with his wife as meaning 'I can drop my little girl off at school in the morning and, you know, if I need to get her in the day I can jump in a car and sort her out' and returned to the same theme later in the interview to say 'rather than leaving at seven in the morning 
when my little girl is still asleep and getting back at seven at night when she's in bed, I could try and make time in the working day'. In being located on the edge of an Area of Outstanding Natural Beauty ${ }^{1}$ not far from his home town, the distillery business allowed Paul and his wife to pursue flexible working patterns as well as a preferable setting in which to fulfil their role as parents of a young daughter.

Such observations offer an important lead on how entrepreneurial families might be analysed as bound up with, and certainly not partitioned from, family life. Not only do we see that rather than a clear division between work and home, participants are actively engaged 'strategies of coordination' (Jarvis, 1999). We also see here how entrepreneurial work is woven through the 'doing' of family practice (Morgan, 1996). Thus, Paul's depiction of the business as a means of making his envisaged familial life a reality was bound up with his desire to demonstrate a committed and present form of fatherhood (Gatrell et al., 2015; Dermott \& Miller, 2015) and engage in what Such $(2009,81)$ refers to as 'morality talk' involving a 'discourse of compromise, mutuality and balance' which is used by many men to articulate 'a moral fatherhood built around the notion of the involved, flexible father'.

Interviews often took narrative forms which foregrounded entrepreneurial epiphanies and moments of shared achievement and pride interwoven with the ongoing experience of interpersonal affinities manifest in the quotidian accomplishment of personal and interpersonal everyday life. An interesting illustration of this was Austin who gave numerous accounts of his working life during the interview, and the preceding tour of the distillery and tasting rooms run by he and his wife, that were characterised by their expression of intimacy with his long-time partner. Thus, he described 'that amazing moment' of setting off to the first trade event 'with cases of the gin we'd made together and just having that buzz and excitement that we're doing this exciting, quite brave, thing together' and later explained how starting the distillery business meant that 'it's a lot of stress, some very long days but worth it as we're making a living together, and that has tested us in so many ways but brought us so much closer together in every possible way'. Notably, then, for many interviewees the confirmation of work and mutual passion invested in their craft enterprise meant that work afforded chances for affinities to play out and find expression, often through 'being in the moment' together and mutually experiencing the highs and lows of entrepreneurial progress (Mason, 2018). Such 'affective interactions' (Gabb, 2008) demonstrate how working together, for the likes of Austin, enhance feelings of intimacy and attachment. If, following Jamieson (1998, p.8, original emphasis), we conceive of intimacy as 'any form of close association in which people acquire familiarity, that is

\footnotetext{
${ }^{1}$ Area of Outstanding Natural Beauty are areas of landscape in England and Wales designated as being of special importance for the purposes of conservation and development.
} 
shared knowledge about each other' than the proximities and mutual passions, practices and experiences of running a craft enterprise together are clearly a field in which intimacy can flourish.

For the majority of interviewees, a predominant and valued feature of working lives was, as in Cederholm and Åkerström's (2016) study, the holistic nature of entrepreneurial activities that brought together personal passions, mutual interests and intimate social ties with close family. However, there was also acknowledgment that this blurring of work and life boundaries brought with it the risk of boundlessness. Yasmin, who runs a distillery with her spouse in a remote rural area, explained that:

'It's not just work, it's your life. But, I suppose, it is how you set up. I would say that I suppose any craft company that are working by hand and as a family and that's how it works, it could become your life. So, we start at probably six and we'll finish work probably seven or eight o'clock tonight.'

Such resonates with Gregg's (2013: 3) assertion that it is 'the sense of fulfilment and gratification many workers derive from their jobs, which makes them susceptible to letting professional duties spill into other times and places' (Gregg, 2013: 3). Adding to this, this spilling over is in many examples offered here shown to be a desired feature of craft entrepreneurship. Thus, for Kal, who ran his distillery with his wife from their home in a rural area of Southwest England, this meant that 'one of our main things' was 'to be able to do something literally from home, together, and make a living from it'. As Mason (2008; 2018) explains, kinship affinities are often most keenly felt through sensory relationality. As they engage in attempts to align entrepreneurial activities with familial relationships in deeply meaningful ways, the emphasis on togetherness and co-presence foregrounds the desire for work and family life to be bound together rather than temporally and spatially separated. Thus, both Yasmin and Kal spoke of how working together with their spouses on something both they and their spouses felt passionate about, and which allowed them to be present in each other's working lives without complying to a distinct work-life boundary, was an intentionally goal and a motivation for establishing their distilleries.

Exploring these themes further during interviews brought forward detailed accounts of how working practices and work-life balance were experienced in relation to negotiating task and role allocation within the business. For many, this meant accounting for the different preferences and complementary skills of themselves and their partners but also, it's important to note, frequently showed conformity to gendered role allocations identified elsewhere, for example, in the craft beer industry (Thurnell-Read, In Press). Kal illustrated this well when he explained that: 
'I look after all the distilling and blending side of things and the marketing, doing all the branding and design sort of things and then [my wife] will do all our distribution, work our supply networks, the day to day admin. All of that aside, and then she is of course chief taster [laughs]'

Typically, all interviewees spoke of such divisions of labour as being primarily informed by the different skills, abilities and preferences of those involved. Yet, there were some notable trends for divisions of labour to follow rather traditional gendered lines. Thus, when Felix explains how he and his partner where 'quite opposite' in that 'she focuses on making sure we're not going bankrupt and deals with a lot of accounts and I deal with the distilling...I am a mañana man, where she makes me do things today and so we work really well together' he invokes an image of the reliable wife playing a supporting role to his own creative dynamism. While all but one of the five female interviewees had hands on experience of distilling, coupled with knowledge and passion for artisan spirits to match their male counterparts, so too were they all more likely than male interviewees to be engaged primarily or solely in activities related to administration, marketing and communication. Notably, there was some apparent ease with which male interviewees could choose to exempt themselves from such tasks. This was especially the case where social interaction with the general public was required. Both Felix and Archie, for example, alluded to passing social media communications with current or potential customers and suppliers as something they had willingly passed on to their spouses to handle, while Terry said that unlike his partner he was 'really not naturally well suited' to the 'charm offensive' required during face-to-face events such as drinks festivals and tutored tastings. These findings suggest that gendered power dynamics are at play in spite of the apparent sincerity of male interviewees desire to portray their work as a mutually beneficial and equitable joint enterprise. Further still, we might see here echoes of both recent findings by Land, Sutherland and Taylor (2018) that expose the gendered barriers limiting women's entry into and movement through the spaces of the craft beer and the work of Gregg (2013) and Naudin and Petal (2017) showing that the burdens of the imperative to display and enact oneself through digital communication technology fall more heavily on women than on men.

\section{Concluding discussion}

The findings outlined above have explored the ways in which entrepreneurial activity and personal relationships are intertwined. In contrast to the traditional casting of public work and private domestic life as separate spheres, interviewees who worked with partners, siblings and friends foregrounded such social connections as being fundamental to the character of their businesses and the quality of their work. The analysis has therefore shown that routines of intimacies are not easily separated out from entrepreneurial activities in working life (Land and Taylor, 2010) and are, in fact, 
central to the envisioning of a lifestyle which is both familial and entrepreneurial. That many interviewees invoke an image of their work at the distillery as being a culmination of various aspects of their personal life - their interests and passions, their rejection of previous occupations or career paths, their establishment of relationships and families - attests to the considerable blurring of work, leisure and lifestyle (Smith Maguire, 2017). Further, whilst both public and academic discourses of craft have long emphasised independence and autonomy (Dormer, 1994) and ascribed meaning to craft practice as a means of self-exploration and expression (Korn, 2013), craft distillers here appear to encourage and value the intermixing of public entrepreneurship and private life and the interplay of work activities with non-work activities and relations. Thus, building a craft enterprise jointly run by spouses or intimate partners, where the text, images and narratives used to promote the product incorporate themes of family identity, is an example of 'displaying' family (Finch, 2007). Those craft entrepreneurs who incorporate familial and other intimate relationships into their brand are 'doing' (Morgan, 1996) and 'performing' (Finch, 2007) family and kinship through their work in a particular kind of way. Familiness is therefore a resource that is used and worked upon and with during craft enterprise but also a series of 'affinities' providing meaningful moments of connection (Mason, 2018) and intimacy (Jamieson, 1998).

That the likes of Danny and Jacqueline invoke family histories in framing their present work, and others such as Chris speak of a future in which their children will become increasingly involved in running the business, attests to the importance of traditions, memory and imagination in our understanding of familial identities (Smart, 2007). Whilst such can be seen to add value to their products (Smith Maguire, Strickland, \& Frost, 2013), the analysis has also shown how the past, present and future configurations of family imaginaries are often present in accounts of current entrepreneurial activities. To further this analysis, it is useful to follow Atkinson's (2013b: 62) interesting observation that craftwork which takes place in 'small paces' - in glass blowing studios or, as here, gin distilleries - where, nonetheless 'the smallest, most local phenomena can thus, be developed into a wide set of conceptual, formal ideas' (Atkinson, 2013b). The interviews reveal a wiliness on the part of participants to talk about a wider range of issues than just the act of making and selling gin. We see how relationships between family members and intimate partners lies at the heart of these craft enterprises and, from that, can draw insights into workplace subjectivities, personal identity, lifestyle aspirations and intimate relationships.

While many craft enterprises are often vocally opposed to corporate rationality emblematic in the business actions of sector dominators (Thurnell-Read, 2019), the discourses of entrepreneurship notably fail to challenge the 'productivist' ethos which the likes of Weeks (2011) have sought to problematise. Further, upholding craft entrepreneurship as a solution to the lack of family friendly 
working conditions in the modern neoliberal economy risks furthering an increasingly widespread discourse that posits the development of 'entrepreneurial character' as the sole appropriate personal response to structural inequality and uncertainty (Morrin, 2018). Indeed, in the accounts of participants we see palpable examples of the seductive appeal of commitment to idealised images of fulfilling and meaningful creative work (Ekman, 2013). These can be are striking in their expansiveness; as Austin lamented, the craft enterprise could become something 'all encompassing' with 'no off switch' because it involves both him and his partner and so readily blurs their public and private lives. In addition to any commitment of money, time and effort, many of the craft enterprises examined here entail huge investments of emotion and identity whereby the success of the business will not just be measured in sales, turnover and profit but in personal fulfilment, interpersonal affinities and both present and potential familial contentment. Such is clearly viewed positively by most participants. In contrast to the imperatives to invest oneself into one's work in more corporate settings (Ekman, 2013; Gregg, 2013), there was a strong sense that interviewees felt themselves and their businesses to be the primary beneficiaries of their investment of selfhood into their work.

The implications of this research encourage a loosening of the grip of images of entrepreneurial work as sealed off from the social world of emotions and intimacy and to give due regard to ties of friendship, kin and family and to explore how they become animated in both the strategic decisions and the everyday affective practices of family enterprises. As Glucksmann (2005, p. 22) warns, 'the organisation and distribution of work cannot be explained solely from within work'. How work is organised and the form these businesses take is influenced by decisions relating to familial priorities and aspirations, to intergenerational affinities and obligations and to both personal and interpersonal identity formations. We might again draw on Atkinson (2013a), who refers to 'the choreography of making' to describe the postures, positioning and feelings of bodies at work in the craft studio but, in this case, expand this by suggesting that this choreography goes beyond just the act of making but applies to the wider work of striving to ensure that the circumstance in which the craft enterprise takes place accord to a range of values held by individuals and negotiated between intimate partners. Thus, many of the individuals interviewed are actively engaged in an act of choreographing the spheres of family and work, and the expressions of private and public self, in ways which are more closely aligned than other forms of employment might afford.

Whilst interviewees frequently communicated about their work organisation via positive frames of personal choice, complementarity and shared passion, it remains unclear how far these discourses might serve to occlude power differentials between family members. Given that Mulholland (2003) has illustrated how women become increasingly marginalised within family enterprises as corporate 
leadership structures become formalised with company growth and expansion, further longitudinal research of some of the numerous emerging craft enterprises may prove valuable in revealing the interweaving of work and private family life over time as upheavals in either spheres, such as business failure or family breakdown or estrangement, impact upon and reshape the realities of daily life represented by the at times idealistic narratives offered here. Longitudinal research might also fill out initial observations made here in relation to the ambitions to a form of 'involved' fatherhood described by several of the male participants (Dermott \& Miller, 2015) and to unpick any discrepancies between stated and actual conduct in relation to gendered divisions of labour and the shifting balances of power within a growing or, possibly failing, enterprise. With this in mind, the growing number of enterprises across the craft sectors and creative economies require ongoing research to further evaluate the interplay of personal relationships and working life in a ways that allows their entanglement to be examined and explained.

\section{References}

Aldrich, H. E., \& Cliff, J. E. (2003). The pervasive effects of family on entrepreneurship: Toward a family embeddedness perspective. Journal of business venturing, 18(5),573-596.

Allen, G. A. (1996). Kinship and friendship in modern Britain. Oxford: Oxford University Press.

Atkinson, P. (2013a). Blowing hot: The ethnography of craft and the craft of ethnography. Qualitative Inquiry, 19(5),397-404.

Atkinson, P. (2013b). Ethnography and craft knowledge. Qualitative Sociology Review, 9(2),56-63.

Barros, I., Hernangómez, J., \& Martin-Cruz, N. (2017). Familiness and socioemotional wealth in Spanish family firms: An empirical examination. European Journal of Family Business, 7(1-2),14-24.

Bourne, K.A. \& Calás, M. B. (2013). Becoming 'real' entrepreneurs: Women and the gendered normalization of 'work'. Gender, Work \& Organization, 20(4),425-438.

Boyle, R. (2008). From Troubleshooter to The Apprentice: The changing face of business on British television. Media, Culture \& Society, 30(3),415-424.

Branson, R. (2008). Business stripped bare: Adventures of a global entrepreneur. London: Random House.

Brinkmann, S., \& Kvale, S. (2018). Doing Interviews. Second Edition. London: Sage.

Bröckling, U. (2015). The Entrepreneurial Self: Fabricating a new type of subject. London: Sage. 
Cederholm, E. A., \& Åkerström, M. (2016). With a little help from my friends: Relational work in leisure-related enterprising. The Sociological Review, 64(4), 748-765.

Charmaz, K. (2006). Constructing Grounded Theory: A practical guide through qualitative analysis. London: Sage.

Cope, S. 2014 Small Batch: Pickles, Cheese, Chocolate, Spirits, and the Return of Artisanal Foods. Lanham: Rowman \& Littlefield.

Crang, P. H. I. L., \& Martin, R. L. (1991). Mrs Thatcher's vision of the 'new Britain' and the other sides of the 'Cambridge phenomenon'. Environment and Planning D: Society and Space, 9(1),91-116.

Dermott, E., \& Miller, T. (2015). More than the sum of its parts? Contemporary fatherhood policy, practice and discourse. Families, Relationships and Societies, 4(2),183-195.

Dodd, C. (2018). 'Can the gin market keep on growing?', The Spirits Business, 5th October.

Dormer, P. 1994. The Art of the Maker: Skill and its meaning in art, craft and design. London: Thames \& Hudson.

Ekman, S. (2012). Authority and autonomy: paradoxes in modern knowledge work. Basingstoke: Palgrave Macmillan.

Ekman, S. (2013). Fantasies about work as limitless potential-how managers and employees seduce each other through dynamics of mutual recognition. Human Relations, 66(9),1159-1181.

Finch, J. \& Mason, J. (2003). Negotiating family responsibilities. Routledge.

Finch, J. (1983). Married to the Job: Wives' Incorporation in Men's Work. London: Allen an Unwin.

Finch, J. (2007). Displaying families. Sociology, 41(1),65-81.

Fincham, B. (2008). Balance is everything: Bicycle messengers, work and leisure. Sociology, 42(4),618-634.

Fitzgerald, M. A., \& Muske, G. (2002). Copreneurs: An exploration and comparison to other family businesses. Family Business Review, 15(1),1-16.

Gabb, J. (2008). Researching intimacy in families. Basingstoke: Palgrave Macmillan.

Gatrell, C. J., Burnett, S. B., Cooper, C. L., \& Sparrow, P. (2015). The price of love: The prioritisation of childcare and income earning among UK fathers. Families, Relationships and Societies, 4(2), 225-238. 
Glucksmann, M. (2005). Shifting boundaries and interconnections: extending the 'total social organisation of labour'. The Sociological Review, 53,19-36.

Glucksmann, M. A. (1995). Why 'work'? Gender and the 'total social organization of labour'. Gender, Work \& Organization, 2(2),63-75.

Gregg, M. (2013). Work's intimacy. Cambridge: Polity Press.

Hashemi, M. (2019). Bedouins of Silicon Valley: A neo-Khaldunian approach to sociology of technology. The Sociological Review, 67(3),536-551.

Jamieson, L. (1998). Intimacy: Personal Relationships in Modern Societies. Oxford: Blackwell.

Jamieson, L., Morgan, D., Crow, G., \& Allan, G. (2006). Friends, neighbours and distant partners: extending or decentring family relationships?. Sociological research online, 11(3),1-9.

Jarvis, H. (1999). The tangled webs we weave: household strategies to co-ordinate home and work. Work, Employment and Society, 13(2),225-247.

Korn, P. (2013). Why We Make Things and Why it Matters: The education of a craftsman, Boston: Godine.

Kuehn, K. M., \& Parker, S. (2018). One of the blokes: Brewsters, branding and gender (in) visibility in New Zealand's craft beer industry. Journal of Consumer Culture.

Land, C., \& Taylor, S. (2010). Surf's up: Work, life, balance and brand in a new age capitalist organization. Sociology, 44(3),395-413.

Land, C., Sutherland, N., \& Taylor, S. (2018). Back to the Brewster: Craft Brewing, Gender and the Dialectical Interplay of Retraditionalisation and Innovation. In by Bell, E., Mangia, G., Taylor, S. and Toraldo, M. (eds) The Organization of Craft Work. London: Routledge.

Luckman, S. (2015). Craft and the Creative Economy. London: Palgrave Macmillan.

Marston, R. (2019). 'How long can gin stay in high spirits?', BBC News, 16 November 2018.

Mason, J. (2008). Tangible affinities and the real life fascination of kinship. Sociology, 42(1),29-45.

Mason, J. (2018). Affinities: Potent connections in personal life. Cambridge: Polity.

Morgan, D. (1996). Family Connections: An introduction to Family Studies. Cambridge: Polity Press. 
Morrin, K. (2018). Tensions in Teaching Character: How the 'Entrepreneurial Character' is Reproduced, 'Refused', and Negotiated in an English Academy School. Sociological Research Online, 23(2),459-476.

Mulholland, K. (1997). The family enterprise and business strategies. Work, Employment and Society, $11(4), 685-711$.

Mulholland, K. (2003). Class, gender and the family business. Basingstoke: Palgrave Macmillan.

Naudin, A., \& Patel, K. (2017). Entangled expertise: Women's use of social media in entrepreneurial work. European Journal of Cultural Studies,

Ocejo, R. E. (2017). Masters of Craft: Old jobs in the new urban economy. Princeton: Princeton University Press.

O'Connor, E. (2005). Embodied knowledge: The experience of meaning and the struggle towards proficiency in glassblowing. Ethnography 6(2), 183-204.

Randerson, K., Bettinelli, C., Fayolle, A., \& Anderson, A. (2015). Family entrepreneurship as a field of research: Exploring its contours and contents. Journal of Family Business Strategy, 6(3),143-154.

Rydzik, A., \& Ellis-Vowles, V. (2018). 'Don't Use "the Weak Word"': Women Brewers, Identities and Gendered Territories of Embodied Work. Work, Employment and Society, OnlineFirst.

Sennett, R. 2008. The Craftsman. London: Allen Lane.

Snyder, G. J. (2012). The city and the subculture career: Professional street skateboarding in LA. Ethnography, 13(3),306-329.

Smart, C. (2007). Personal Life: New directions in sociological thinking. Cambridge: Polity.

Smith Maguire, J. (2013). Provenance as a filtering and framing device in the qualification of wine. Consumption Markets \& Culture, 16(4),368-391.

Smith Maguire, J. (2017). 'Consumption of Leisure' in Keller, M., Halkier, B., Wilska, T. A., \& Truninger, M. (Eds.). Routledge Handbook on Consumption. Abingdon: Routledge.

Smith Maguire, J., Strickland, P., \& Frost, W. (2013). Familiness as a form of value for wineries: a preliminary account. Journal of wine research, 24(2),112-127.

Such, L. (2009). Fatherhood, the morality of personal time and leisure-based parenting' in T. Kay (Ed) Fathering Through Sport and Leisure. Abingdon: Routledge. 
Taylor, E. (2018). 'How Gin Bounced Back From Decades of Decline to Become London's Latest It Drink', Vogue, 11 June 2018.

Taylor, S. (2015). A new mystique? Working for yourself in the neoliberal economy. The Sociological Review, 63,174-187.

Thurnell-Read, T. (2014). Craft, tangibility and affect at work in the microbrewery. Emotion, Space and Society, 13, 46-54.

Thurnell-Read, T. (2019). A thirst for the authentic: craft drinks producers and the narration of authenticity. The British journal of sociology, 70(4), 1448-1468.

Thurnell-Read, T. (In Press). 'Gender and Craft Drinks' in E.J. Abbots (eds) Routledge Companion to Gender and Food. Abingdon: Routledge.

Waight, E. (2019). Mother, consumer, trader: Gendering the commodification of second-hand economies since the recession. Journal of Consumer Culture, 19(4),532-550.

Warr, P., \& Inceoglu, I. (2018). Work orientations, well-being and job content of self-employed and employed professionals. Work, employment and society, 32(2),292-311.

Wee, L., \& Brooks, A. (2012). Negotiating gendered subjectivity in the enterprise culture: Metaphor and entrepreneurial discourses. Gender, Work and Organization, 19(6),573-591.

Weeks, K. (2011). The Problem with Work: Feminism, Marxism, Antiwork Politics, and Postwork Imaginaries. Durham, NC: Duke University Press.

Weeks, K. (2011). The problem with work: Feminism, Marxism, antiwork politics, and postwork imaginaries. London: Duke University Press.

Welsh, D. H., Memili, E., Rosplock, K., Roure, J., \& Segurado, J. L. (2013). Perceptions of entrepreneurship across generations in family offices: A stewardship theory perspective. Journal of Family Business Strategy, 4(3),213-226. 